\title{
Mitochondrial proliferation in the permanent vs. temporary cold: enzyme activities and mRNA levels in Antarctic and temperate zoarcid fish
}

\author{
M. Lucassen, A. Schmidt, L. G. Eckerle, and H.-O. Pörtner \\ Alfred-Wegener-Institute for Polar and Marine Research, \\ Ecophysiology and Ecotoxicology, 27568 Bremerhaven, Germany
}

Submitted 5 March 2003; accepted in final form 4 August 2003

Lucassen, M., A. Schmidt, L. G. Eckerle, and H.-O. Pörtner. Mitochondrial proliferation in the permanent vs. temporary cold: enzyme activities and mRNA levels in Antarctic and temperate zoarcid fish. Am J Physiol Regul Integr Comp Physiol 285: R1410-R1420, 2003. First published August 7, 2003; 10.1152/ajpregu.00111.2003.-Adjustments in mitochondrial properties and capacities are crucial in acclimatization to seasonal cold and in evolutionary cold adaptation of marine ectotherms. Although long-term compensatory increments in aerobic capacity of fish tissues have frequently been described in response to cold, much less is known about transitional phases and gene expression patterns involved. We investigated the time course of adjustment to acute cold in liver of eurythermal eelpout Zoarces viviparus. Whereas citrate synthase (CS) activity rose progressively in liver, cytochrome $c$ oxidase (COX) activity was not altered during cold acclimation. Species-specific RNA probes were used to determine mRNA levels. CS mRNA (nuclear encoded) displayed a delayed, transient increase in response to cold, such that transcript levels did not parallel the change in enzyme activity. The enzyme activities and mRNA levels in the confamilial Antarctic Pachycara brachycephalum indicate cold compensation of CS activity in this cold-adapted species. The ratio of CS and COX activities was elevated in acclimation and adaptation to cold, indicating enhanced citrate synthesis over respiratory chain capacities in cold-adapted liver mitochondria. This may support enhanced lipid synthesis typically found in cold. The ratio of enzyme activity and transcript levels differed largely between $Z$. viviparus populations from the Baltic and North Seas, indicating the influence of unidentified parameters other than temperature. Transcript levels may not be tightly correlated with enzyme activities during thermal adaptation and thereafter. The time course of the acclimation process indicates that regulation at the translational and posttranslational levels predominates in adjustment to moderate thermal challenges.

cold acclimation; cytochrome $c$ oxidase; citrate synthase; RNase protection assay; Zoarces viviparus; Pachycara brachycephalum

TEMPERATURE IS ONE OF THE most important abiotic factors in marine ecosystems due to its large impact on all biological processes. Therefore, it was hypothesized

Address for reprint requests and other correspondence: M. Lucassen, Alfred-Wegener-Institute for Polar and Marine Research, Ecophysiology and Ecotoxicology, Columbusstrasse, 27568 Bremerhaven, Germany (E-mail: mlucassen@awi-bremerhaven.de). that the constraints and tradeoffs involved in thermal adaptation and the energy-demanding capacity to withstand temperature fluctuations limit individual species to a characteristic thermal niche and thereby define macroscale biogeography of marine ectotherms $(25,26,27)$. Temperature alters the velocity of chemical and enzymatic reactions, rates of diffusion, membrane fluidity, and protein structure (for review, see Ref. 33). When exposed to cold, ectothermic organisms have to compensate for the decelerating effect of temperature on these processes and maintain functional balance between ATP formation and ATP demand. Acclimation to seasonal cold is well known to cause a rise in aerobic capacity by increasing mitochondrial density and/or the capacity of mitochondrial enzymes in fish $(1,5,8,9,19,36)$. Mitochondria are the primary site of ATP production in animals. Therefore, mitochondrial density and capacity reflect aerobic energy turnover. As a tradeoff, the high energy demand for the synthesis of mitochondria and the generation and maintenance of proton gradients despite proton leakage causes mitochondrial maintenance to comprise a large proportion of standard metabolic rate (cf. Refs. 26,28 , and 29).

During seasonal cold, an increase in density as well as in temperature-specific capacity of mitochondria have been reported in fish (cf. Ref. 9). During adaptation to eurythermal cold in a latitudinal cline, increments in capacity have also been observed $(34,39)$, likely linked to modifications in cristae surface densities and/or enzyme densities and properties. In permanently cold-adapted stenothermic organisms, however, even higher mitochondrial densities have been observed, but it has been postulated that these mitochondria exhibit lower capacities of substrate oxidation and rates of oxygen consumption than mitochondria of eurythermal ectotherms $(28,29)$. There is an ongoing discussion about the level of metabolic cold adaptation in permanently cold-adapted fish $(2,3,26,29,35,44)$, but cold compensation of aerobic metabolic enzyme capacities has repeatedly been demonstrated in temperate and Antarctic fish (e.g., Refs. 4, 13, and 16).

The costs of publication of this article were defrayed in part by the payment of page charges. The article must therefore be hereby marked "advertisement" in accordance with 18 U.S.C. Section 1734 solely to indicate this fact. 
Measurements of key enzymes of the citric acid cycle, mostly citrate synthase (CS), on the one hand and oxidative electron transport components, mostly cytochrome $c$ oxidase (COX), on the other, are widely used to monitor the long-term acclimation of fish mitochondria (36). These increments likely reflect modifications in both the properties and the numbers of the mitochondria present (9). Upregulation of both enzymes usually takes place at the transcriptional, translational, and/or posttranslational levels $(1,13,18)$. Besides, changes in membrane properties during cold acclimation contribute to the modification of COX activities $(42,43)$.

The molecular mechanisms by which increases in mitochondrial densities and capacities are achieved and maintained are an active area of research (for review, see Refs. 14 and 19). Since most of the complexes in electron transport have both nucleus- and mitochondria-encoded subunits, mitochondrial biogenesis is complicated by the need to coordinate the expression of the mitochondrial and nuclear genomes. A number of relevant regulatory factors [nuclear respiratory factor (NRF1, NRF2), and elements (OXBOX, REBOX, MT1, MT3, MT4) have so far been described. The coordinated expression of different genes seems to be achieved at least in part by shared sensitivities to specific transcription factors $(7,12,20,22)$. Although several bioenergetic factors influence the expression of essential genes (see Ref. 19), essentially no information is available about the signal(s) and the primary receptors operative during thermal adaptation.

In addition to the scarcity of knowledge concerning the mechanisms stimulating mitochondrial proliferation, little is known about the changes over time during acclimation of ectothermic organisms to seasonal cold. In fact, some evidence for the processes involved in mitochondrial proliferation might arise from time-resolved studies of mitochondrial enzyme capacities, their levels of transcripts, and the potential regulatory factors involved. The aim of the present study was therefore to investigate the effect of acute cold exposure on the expression of mitochondrial enzymes in the eurythermal eelpout Zoarces viviparus. We have studied the acclimation process by analyzing maximum activities as well as transcription levels of CS and COX in liver. These key enzymes were chosen because they are localized in either matrix or membrane and because their respective genes are either nucleus-encoded (CS) or both mitochondria- and nucleus-encoded (COX). Since no RNA probes were available for CS from fish, we isolated and characterized fragments of the CS gene from $Z$. viviparus and the confamilial Pachycara brachycephalum. $Z$. viviparus has been exposed to a moderate temperature shift from $10^{\circ} \mathrm{C}$ to $3.5^{\circ} \mathrm{C}$. These temperatures were chosen from well within the thermal tolerance window described for this species (40), thereby avoiding any general stress response. We chose to study liver tissue because our previous study demonstrated that liver as an aerobic organ is most sensitive to the thermal stimulus (40). The results indicate an important role of posttranscrip- tional modifications in establishing the new steady state of mitochondrial functions during cold acclimation. Comparisons with the levels of expression and the activities of CS and COX from $P$. brachycephalum should provide insight into potential differences between the mechanisms of acclimatization to seasonal cold and of adaptation to the permanent cold of polar areas.

\section{MATERIALS AND METHODS}

Animals. Eurythermal common eelpout $Z$. viviparus from the North Sea population (mass: $46.1 \pm 24.9 \mathrm{~g}$ ) were caught during late summer 2001 in the German Bight near Helgoland. Fish were kept at $10.0 \pm 0.1^{\circ} \mathrm{C}$ and $30 \%$ salinity. For cold acclimation, the temperature was reduced from $10(t=0$ days) to $3.5^{\circ} \mathrm{C}$ within $12 \mathrm{~h}$ and kept at $3.5 \pm 0.1^{\circ} \mathrm{C}$ for the remaining time. Samples $(n=5)$ were taken once every $24 \mathrm{~h}$ from the beginning of the cooling procedure until day 7 and then at days $9,11,15$, and 25 . At $t=0$, a reference sample $\left(10^{\circ} \mathrm{C}\right)$ was taken. The animals were evenly distributed over the whole experimentation time with regard to size and sex. $Z$. viviparus from the Baltic Sea population (mass: $88.5 \pm$ $36 \mathrm{~g}$ ) were caught during June 2000 in the Kieler Förde. Fish were kept at $18 \%$ o salinity and were acclimated to $3.0 \pm 0.5^{\circ} \mathrm{C}$ (cold-acclimated) and $13.5 \pm 0.5^{\circ} \mathrm{C}$ (warm-acclimated) for at least 2 mo. Starting from $10^{\circ} \mathrm{C}$, the temperature was changed at a rate of $1^{\circ} \mathrm{C} /$ day until the final temperature was reached. Benthic Antarctic eelpout, $P$. brachycephalum, were caught at a depth of $500 \mathrm{~m}$ close to King George Island (Antarctic Peninsula) on a cruise with the research vessel Polarstern in May/June 2000. Fish (mass: $60.54 \pm 18.1 \mathrm{~g}$ ) were transferred to Bremerhaven and kept in well-aerated water of $0.0 \pm$ $0.5^{\circ} \mathrm{C}$ and $32-34 \%$ salinity. All fish were kept under a 12 : 12-h light/dark cycle and were fed with shrimps and mussels ad libitum twice a week. Feeding was terminated 5 days before experimentation.

RNA isolation. Animals were slightly anaesthetized with MS-222 (0.3 g/l) before being killed. Samples from different tissues, starting with the most metabolically active, were quickly removed and were frozen instantaneously in liquid nitrogen. For the quantitative isolation of total RNA from frozen tissue, the RNeasy kit (Qiagen, Hilden, Germany) was used. RNA from $P$. brachycephalum was isolated by a modified protocol according to the manufacturer's instructions with a digestion of the tissue by proteinase $K$, since the yield was two- to threefold lower with the standard protocol. mRNA was purified from total RNA by the Oligotex kit (Qiagen). The RNA was quantified spectrophotometrically in triplicate samples. $\mathrm{A}_{260} / \mathrm{A}_{280}$ ratios were always $>1.8$. Formaldehyde agarose gel electrophoresis according to Sambrook et al. (30) was used to verify the integrity of the RNA.

Construction of probes and sequence determination. For the quantification of RNA transcripts of CS and COX genes, RT-PCRs were performed with different sets of primers to construct specific probes from $Z$. viviparus and $P$. brachycephalum. Reverse transcription was performed with Superscript RT (Invitrogen, Karlsruhe, Germany) and the different reverse primers (Table 1) by using mRNA isolated from both fishes as templates. The components were incubated for $1 \mathrm{~h}$ at $37^{\circ} \mathrm{C}$ in (in $\mathrm{mM}$ ) 20 Tris $\cdot \mathrm{HCl}, \mathrm{pH} 8.4,50 \mathrm{KCl}$, $10 \mathrm{DTT}$, and $2.5 \mathrm{MgCl}_{2}$. The following PCR reaction used the degenerate primer pairs from Table 1, which have been designed to amplify cDNA homologous to published sequences for the respective gene. The cDNA was always amplified in a gradient cycler (Tgradient; Biometra, Göttingen, Germany) with Taq polymerase (Invitrogen) and $1.5 \mathrm{mM}$ 
Table 1. Primer list for RT-PCR

\begin{tabular}{cllc}
\hline \hline Fragment & \multicolumn{1}{c}{ Term } & \multicolumn{1}{c}{ Sequence } & Position \\
\hline CS-A & Cisy-F9 & AACTTYCCCACSAACCTSCACCC & $469-491$ \\
& Cisy-B16 & TCAGCCAVACRAGCACTTCCTG & $937-916$ \\
CS-B & CisyPb-F1 & CAGTTCAGTGCCGCATCAC & $499-518$ \\
& CisyPb-B2 & GAAGGAAGGTAGGGGCAGACAG & $867-844$ \\
COX2 & Cox2-F2 & GAACTYCTWCACTTCCACGACCACGC & $55-80$ \\
& Cox2-B4 & CCRCAGATTTCAGARCATTGTCC & $602-580$ \\
\hline
\end{tabular}

All sequences are written from 5' to 3'. The position corresponds to the position of the following genes: Sus scrofa citrate synthase (CS) (Ref. 6; GenBank accession no. M21197); European seabass Dicentrarchus labrax cytochrome $c$ oxidase (COX2) (Ref. 41; GenBank accession no. X74149).

$\mathrm{MgCl}_{2}$, applying 1-min denaturation at $94^{\circ} \mathrm{C}$ and 1-min elongation at $72^{\circ} \mathrm{C}$. For the COX2 fragment, a touchdown program with an annealing temperature from 56 to $47^{\circ} \mathrm{C}\left(-1^{\circ} \mathrm{C} /\right.$ cycle) and a $12^{\circ} \mathrm{C}$ gradient was used, followed by 25 cycles at $52 \pm 6^{\circ} \mathrm{C}$ annealing temperature. The CS fragment was amplified with a touchdown program starting at $59^{\circ} \mathrm{C}\left( \pm 6^{\circ} \mathrm{C}\right)$ until $52^{\circ} \mathrm{C}$ was reached $\left(-1^{\circ} \mathrm{C} /\right.$ cycle $)$, followed by 28 cycles with an annealing temperature at $56 \pm 6^{\circ} \mathrm{C}$. After amplification, a final prolonged elongation step of $8 \mathrm{~min}$ at $72^{\circ} \mathrm{C}$ was introduced to prepare the PCR fragments for cloning. The fragments were purified by gel electrophoresis and the Qiaquick gel extraction kit (Qiagen). For cloning of the fragments, the TOPO TA cloning kit (Invitrogen) was used according to the manual. After separation of some clones, plasmids were isolated from overnight cultures by using the Qiaprep Spin Miniprep kit (Qiagen). To verify the presence and size of inserts, the isolated plasmids were analyzed by restriction digestion with EcoRI. For each fragment, the DNA sequence of positive clones was determined for both strands by MWG-Biotech (Ebersberg, Germany) by using an ABIprism 377 automatic sequencer (Applied Biosystems, Weiterstadt, Germany). Primer construction, assembling, analyses, and alignments of the sequences were performed by using the MacVector 7.0 program package (Oxford Molecular, Oxford, UK). The DNA sequences have been submitted to GenBank and can be obtained under accession nos. AY382596 (ZvCISY), AY382597 (Pb CISY) AY227659 ( $\mathrm{Zv}$ Cox2) and AY227660 ( $P b$ Cox2).

Quantification of RNA. Ribonuclease protection assay (RPA) was performed with the RPA-III kit from Ambion (Austin, TX). Total RNA (10 $\mu \mathrm{g}$ for liver) was simultaneously hybridized at $42^{\circ} \mathrm{C}$ to antisense probes for COX 2 and $\beta$-actin (ACT-B; GenBank accession no. AY227657; unpublished observations) or for the citrate synthase gene (CISY) and ACT-B, respectively. Probes were synthesized by in vitro transcription with T7 or T3 RNA polymerase (Invitrogen), depending on the orientation of the inserts. The above-described PCR clones were digested with PstI (in combination with T7 RNA polymerase) or NotI (with T3 RNA polymerase) to generate a template from which an antisense probe was synthesized. The digestions with PstI were followed by a treatment with Klenow fragment and dNTPs (Invitrogen) for removal of protruding $3^{\prime}$ ends. The probes were labeled with $\left[\alpha-{ }^{32} \mathrm{P}\right] \mathrm{UTP}$ (Amersham Bioscience, Freiburg, Germany). To equalize protected fragment intensities, a specific radioactivity of $1,000 \mathrm{Ci} / \mathrm{mmol}$ was used for COX2 and CISY and of 45 $\mathrm{Ci} / \mathrm{mmol}$ was used for ACT-B. The probes were always freshly prepared for hybridization and were purified by PAGE under denaturing conditions ( $8 \mathrm{M}$ urea, $5 \%$ acryl amide gel, and $1 \times$ Tris-borate-EDTA running buffer; Ref. 28) by using a vertical slab apparatus (Protean II xi; Bio-Rad, München, Germany). To eliminate the DNA templates, the reaction mixture was treated with DNase I (Invitrogen) before electrophoresis. The
RPA was optimized according to the manufacturer's instructions with an RNaseA/T1 dilution of 1:100. After RNase treatment, the RNA:RNA hybrids were coprecipitated with yeast RNA. The RNA was dissolved in $6 \mu$ l loading dye and separated by denaturing PAGE (as above). The size of the protected fragments corresponded to the size of the cloned PCR fragments (Fig.1). All probes were tested in separate lines to ensure that no background bands interfered with the other probe. The COX2 probe showed some smaller background fragments, which could not be diminished by increasing or reducing the RNase concentration and which were present in all samples at the same ratio. Since the probe was in excess and the unprotected probe was completely digested, the analyses of the full-length protected fragments resulted in a reliable quantification. After the gel was dried, radioactivity was detected and quantified with a phosphor storage image system (FLA-5000; Fuji, Tokyo, Japan) and the AIDA software package (Raytest, Straubenhardt, Germany).

Protein isolation and enzyme assays. Frozen tissues were powdered under liquid nitrogen and homogenized briefly in 9 volumes of ice-cold buffer $(20 \mathrm{mM} \mathrm{HCl}, \mathrm{pH} 7.4,1 \mathrm{mM}$ EDTA, $0.1 \%$ Tween 20) with an Ultra Turrax. Cellular debris was removed by $10 \mathrm{~min}$ centrifugation at $1,000 \mathrm{~g}$ and $4^{\circ} \mathrm{C}$. Preliminary tests were performed to ensure complete release of the enzyme from liver tissue by this procedure. COX activity was determined according to Moyes et al. (23) in $20 \mathrm{mM}$ Tris $\cdot \mathrm{HCl}, \mathrm{pH} 8.0$, containing $0.5 \%$ Tween 20 and $0.05 \mathrm{mM}$ reduced cytochrome $c$. Cytochrome $c$ was reduced by the addition of excess sodium dithionite, which was removed by G-25 gel filtration. The decrease in the extinction at $\lambda=550$ $\mathrm{nm}$ was monitored in a spectrophotometer with a thermostat (Beckman, Fullerton, CA) at $3.5,10.0$, and $20^{\circ} \mathrm{C}$. Enzyme activity in units per gram of tissue was calculated by using an extinction coefficient $\left(\epsilon_{550}\right)$ for cytochrome $c$ of $19.1 \mathrm{mM} /$ $\mathrm{cm}$. CS activity was determined according to Sidell et al. (32) in $75 \mathrm{mM}$ Tris $\cdot \mathrm{HCl}, \mathrm{pH} 8.0,0.25 \mathrm{mM}$ DTNB, $0.4 \mathrm{mM}$ acetyl $\mathrm{CoA}$, and $0.4 \mathrm{mM}$ oxaloacetate. The increase in the extinction at $\lambda=412 \mathrm{~nm}$ was measured in a thermostatted spectrophotometer at the same temperatures described for COX. Enzyme activity in units per gram of tissue was calculated by using an extinction coefficient $\left(\epsilon_{412}\right)$ of $13.6 \mathrm{mM} / \mathrm{cm}$ for the dye complex.

Statistical analyses. Statistical significance was tested at the $P \leq 0.05$ level by using one-factor ANOVA with acclimation time as the factor and the post hoc Student-NewmanKeuls test for independent samples. Data were tested for outliers at the $95 \%$ significance level by using Nalimov's test (24). Data are given as means $\pm \mathrm{SE}(n=4-6)$.

\section{RESULTS}

Isolation of cDNA clones for CS and COX2. Reliable RNA probes for specific quantification were not avail- 

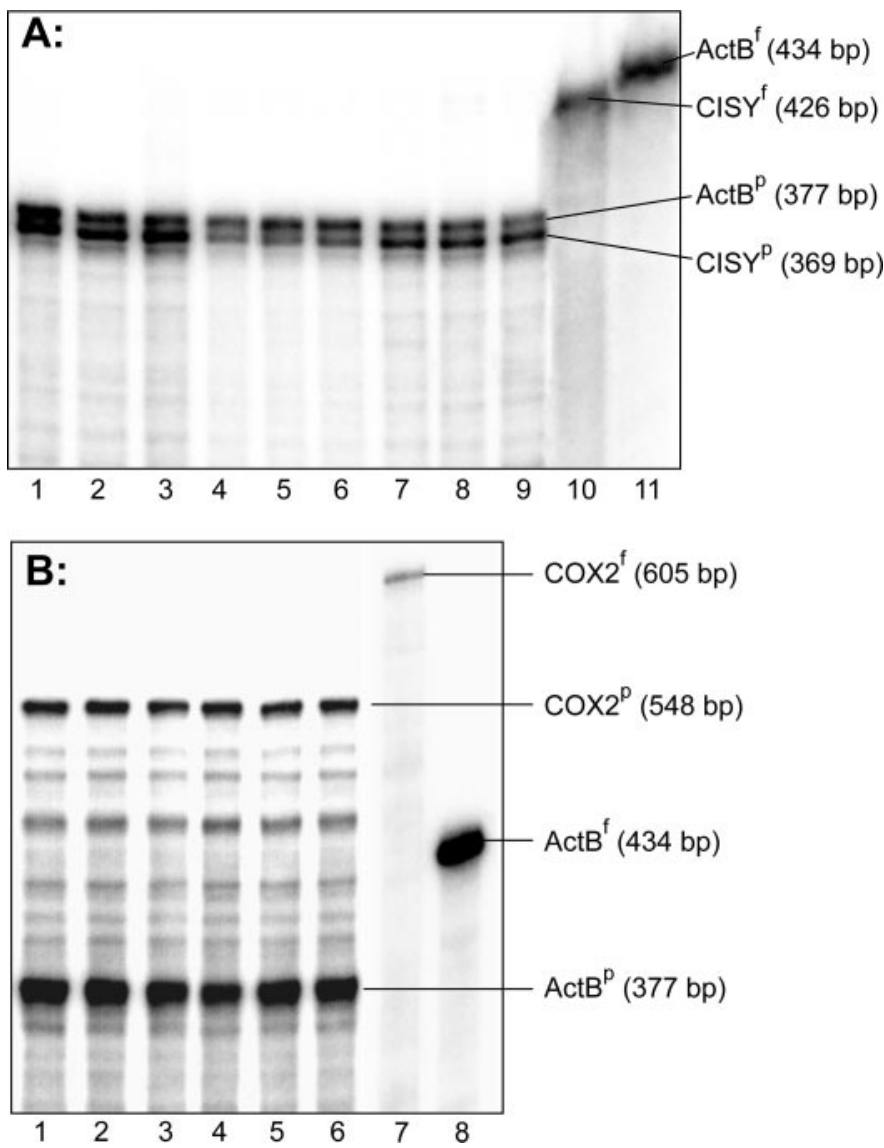

Fig. 1. Representative RNase protection assay of mRNA levels for citrate synthase (CS; $A$ ) and cytochrome $c$ oxidase (COX) subunit 2 $(\mathrm{COX} 2 ; B)$ in the liver of Zoarces viviparus and Pachycara brachycephalum. The amounts of CISY ${ }^{\mathrm{p}}$ and $\mathrm{COX}^{\mathrm{p}}$ relative to ACT- $\mathrm{B}^{\mathrm{p}}$ were determined by ribonuclease protection assay (RPA) as described in MATERIALS AND METHODS. A: lanes 1-3, individual $Z$. viviparus (Baltic Sea, $3.5^{\circ} \mathrm{C}$ ); lanes $4-6, Z$. viviparus (Baltic Sea, $\left.13.5^{\circ} \mathrm{C}\right)$; lanes $7-9, P$. brachycephalum $\left(0^{\circ} \mathrm{C}\right)$. The unprotected probes without digestions are given as control (lanes 10 and 11). Whereas in the warm-acclimated $Z$. viviparus CISY $^{p}$ displayed lower intensities than ACT-B ${ }^{p}$, CISY ${ }^{p}$ intensities were significantly higher in coldacclimated and cold-adapted eelpout. B: lanes 1-2, individual $Z$. viviparus (Baltic Sea, $3.5^{\circ} \mathrm{C}$ ); lanes $3-4, Z$. viviparus (Baltic Sea, $\left.13.5^{\circ} \mathrm{C}\right)$; lanes $5-6, P$. brachycephalum $\left(0^{\circ} \mathrm{C}\right)$. The unprotected probes without digestions are given as control (lanes 7 and 8 ). For COX2 ${ }^{\mathrm{p}}$, no differences relative to ACT- $\mathrm{B}^{\mathrm{p}}$ could be detected. For quantification, a phosphor storage imaging system was used (see Table 2). f, Fulllength RNA probe; $p$, protected fragment.

able for CS. Also, only very few vertebrate and no fish DNA sequences were accessible. We therefore isolated cDNA clones from $Z$. viviparus and $P$. brachycephalum. RT-PCR of mRNA from $P$. brachycephalum liver was performed by using the primer pair CS-A listed in Table 1. A 470-bp fragment could be isolated and cloned. Since the PCR resulted in more than one DNA fragment, the primer pair CS-B was designed after determination of the DNA sequence of this fragment. This primer pair was successfully used to amplify a CS cDNA fragment from $Z$. viviparus (Fig. $2 A$ ). The CS sequences are highly conserved throughout the vertebrates, with $\sim 90 \%$ identity at the protein and $80 \%$ at the DNA level. The two zoarcid ( $Z$. viviparus and $P$. brachycephalum) sequences are completely conserved even at the DNA level. This result is in agreement with further sequence alignments of functional genes like $\mathrm{Na}^{+}-\mathrm{K}^{+}$-ATPase and the $\mathrm{Na}^{+} / \mathrm{H}^{+}$exchanger, which provides evidence for the close relationship of the two species (unpublished observations). These observations are also in line with the conserved role of CS in central metabolism and anabolism and its nucleuslocalized genes. In the same way, cDNA clones have been isolated from the mitochondrially encoded COX2 (primer listed in Table 1). The DNA sequences and the deduced protein sequences (Fig. $2 B$ ) from both organisms share a high degree of identity to other published teleost sequences, especially with the salmoniform Plecoglossus altivelis (protein 93\%, DNA 77\%) and the gadid Gadus morhua (protein 92\%, DNA 81\%). Again, the two zoarcid sequences are much more closely related (protein 97\%, DNA 88\%). Together, these alignments substantiate that the isolated cDNA fragments, subsequently used for the preparation of RNA probes, represent CS and COX2 genes of $Z$. viviparus and $P$. brachycephalum.

Temperature-dependent expression of CS and COX. When $Z$. viviparus (North Sea) acclimated to $10^{\circ} \mathrm{C}$ were brought to $3.5^{\circ} \mathrm{C}$ within $12 \mathrm{~h}$ and maintained at this temperature for nearly $1 \mathrm{mo}$, the relative levels of CS mRNA in liver increased strongly by a factor of 2.1 between days 4 and 6 and returned to control levels $\left(10^{\circ} \mathrm{C}\right)$ thereafter (Fig. 3A). Around days 9-11, expression was even slightly decreased relative to the control group, but this drop was not significant. For the mitochondrially encoded COX2 (Fig. 3B), a similar increase of mRNA contents was found around day 5; however, statistical analysis failed to demonstrate any significance, partly due to the much higher variance between individuals. After $2 \mathrm{wk}$, the level of transcript was found close to control levels.

Analysis of enzyme activities. CS and COX activities were determined at $3.5,10$, and $20^{\circ} \mathrm{C}$ in all experimental groups. The activation energies of both enzymes remained unchanged during acclimation, with values of $38.5 \mathrm{~kJ} / \mathrm{mol}$ for $\mathrm{CS}$ and $32.7 \mathrm{~kJ} / \mathrm{mol}$ for COX, respectively (Fig. 4C). These findings indicate that changing activity levels reflect changing protein levels in the case of CS. In the case of COX, either changing protein levels or changing membrane properties may be behind potential changes in activity (see the introduction). According to Fig. 4, CS activity in liver displayed a significant and persistent increase by a factor of 2 . This higher level of enzyme activity was reached 7-9 days after the onset of cold exposure. For COX, no significant change in activity could be observed during cold exposure. There might have been a small increase in activity on day 1; however, because of the much higher variability in the COX data this transient increment remained statistically nonsignificant.

Analysis of enzyme activity and mRNA in cold-acclimated temperate and cold-adapted Antarctic eelpout. For comparison with the data set obtained in long-term cold-acclimated North Sea eelpout, we analyzed the expression and maximum activities of CS and COX in 
A

ZVCISY -..-.-.-FSAAITAL NSESSFARAY SEGVHKSKYW EFAYEDSMDL IAKLPCIAAK IYRNLYREGS SIGAIDSNLD PbCISY DNFPTNLHPM SQFSAAITAL NSESSFARAY SEGVHKSKYW EFAYEDSMDL IAKLPCIAAK IYRNLYREGS SIGAIDSNLD SSCISY DNFPTNLHPM SQLSAAITAL NSESNFARAY AEGIHRTKYW ELIYEDCMDL IAKLPCVAAK IYRNLYREGS SIGAIDSKLD GgCISY DNFPTNLHPM SQLSAAITAL NSESNFARAY AEGINRTKYW EFVYEDAMDL IAKLPCVAAK IYRNLYRAGS SIGAIDSKLD

100

120

157

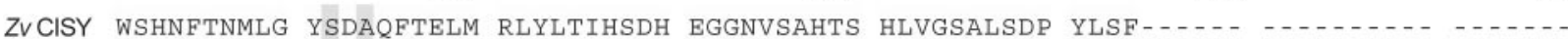
PbCISY WSHNFTNMLG YSDAQFTELM RLYLTIHSDH EGGNVSAHTS HLVGSALSDP YLSFSAAMNG LAGPLHGLAN QEVLVWL Ss CISY WSHNFTNMLG YTDAQFTELM RLYLTIHSDH EGGNVSAHTS HLVGSALSDP YLSFAAAMNG LAGPLHGLAN QEVLVWL GgCISY WSHNFTNMLG YTDPQFTELM RLYLTIHSDH EGGNVSAHTS HLVGSALSDP YLSFAAAMNG LAGPLHGLAN QEVLLWL

B

20

40

60

80

ZvCOX2 HALMIVFLIS TLVLYIIVAM VSTKLTNKYI LDSQEIEIIW TVLPAIILIL IALPSLRILY LMDEINNPLL TIKAVGHQWY PbCOX2 HALMIVFLIS TLVLYIIVAM VSTKLTNKYI LDSQEIEIIW TVLPAIILIL IALPSLRILY LMDELNSPLL TIKAVSHQWY PaCOX2 HALMIVLLIS TLVLYIIVAM VSTKLTNKYI LDSQEIEIIW TVLPAVILIL IALPSLRILY LMDEINDPHL TIKAMGHQWY Gm COX2 HALMIVFLIS TLVLYIIVAM VSTKLTNKYI LDSQEIEIIW TVLPAVILIL IALPSLRILY LMDEINDPHL TIKAMGHQWY

100

$\begin{array}{ll}Z v \text { COX2 } & \text { WSYEYTDY } \\ \text { PbCOX2 } & \text { WSYEYTDY } \\ P a C O X 2 & \text { WSYEYTDY } \\ \text { Gm COX2 } & \text { WSYEYTDY } \\ & \\ Z v \text { COX2 } & \text { ASRPGVFY } \\ P b \text { COX2 } & \text { ASRPGVFY } \\ P a C O X 2 & \text { ASRPGVFY } \\ \text { Gm COX2 } & \text { TSRPGVFY }\end{array}$
120

140

160

Fig. 2. Sequence alignment of deduced CS and COX peptides. A: cloned RT-PCR-products from Zoarces viviparus and $P$. brachycephalum were translated into the amino acid sequence ( $\mathrm{Z} v$ CISY; $P b$ CISY), resulting in 1 open reading frame, and compared with the CS genes from Sus scrofa (Ss CISY; GenBank accession no. M21197) and the protein sequence from Gallus gallus (Gg CISY; GenBank accession no. P23007). B: translated COX2 sequences $(\mathrm{Z} v$ COX2; $\mathrm{Pb} \mathrm{COX} 2)$ are compared with the closest related fish sequences published so far: Plecoglossus altivelis (Pa COX2; GenBank accession no. NC002734) and Gadus morhua (Gm COX2; GenBank accession no. X99772; Ref. 15). Conserved mismatches are highlighted in light gray and nonconserved mismatches in dark gray.

long-term cold-acclimated eelpout $Z$. viviparus from the Baltic Sea and in the cold-adapted Antarctic eelpout $P$. brachycephalum. The primary DNA sequences of CS (see above) and $\beta$-actin (unpublished observations) from both organisms are completely conserved; therefore, RNA probes used in the RPA should work for both organisms with the same affinity. Since the zoarcid DNA sequences of COX2 differed by $\sim 12 \%$, speciesspecific probes with the same specific radioactivity were used in the highly sensitive RPA for comparing expression levels between the two species. In Fig. 1, a representative RPA is given. The results are summarized in Table 2.

Both the cold-acclimated Baltic Sea eelpout and $P$. brachycephalum showed an increased level of CS expression relative to the warm-acclimated $\left(13.5^{\circ} \mathrm{C}\right) \mathrm{Bal}-$ tic Sea control group but not if compared with the North Sea group acclimated to $10^{\circ} \mathrm{C}$. Whereas in $P$. brachycephalum this higher level of mRNA was accompanied by a higher CS activity, enzyme activity in the cold-acclimated Baltic population was only slightly, but not significantly, increased despite significantly augmented mRNA levels. In contrast, cold-induced augmentation of CS activity was much more pronounced and significant in the North Sea population based on a small but nonsignificant increase in mRNA, which started from already elevated mRNA levels if compared with the warm-acclimated Baltic population.

A different pattern developed for COX (Table 2). Long-term cold acclimation did not affect the level of mRNA or maximal activity within Baltic Sea and North Sea populations, respectively. However, COX2 mRNA levels as well as activities were significantly higher in North Sea than in Baltic Sea populations regardless of acclimation temperature. The coldadapted $P$. brachycephalum displayed activities and mRNA levels very close to the results found in the Baltic Sea population.

Since the North Sea and Baltic Sea populations showed remarkable differences in long-term cold acclimation, we analyzed the hepatosomatic indices (HSI) and the condition factors of the investigated specimens. During cold acclimation, neither the fish from the North Sea nor the Baltic Sea populations displayed 


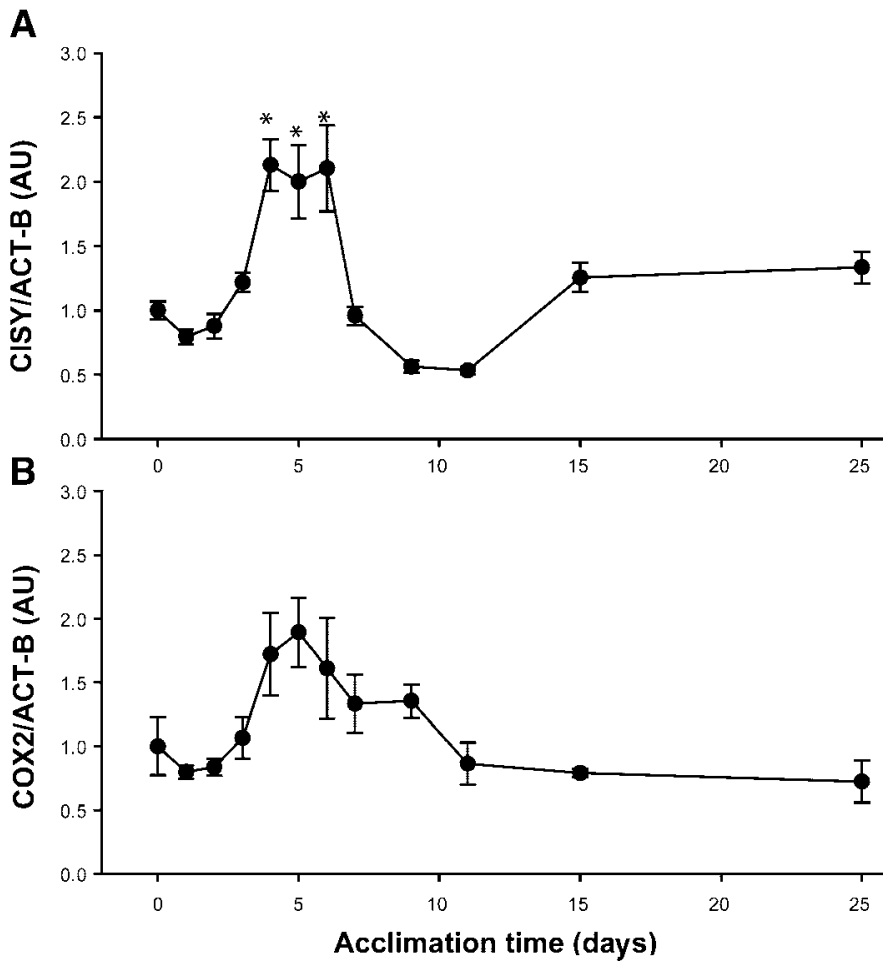

Fig. 3. Effects of temperature acclimation over time on mRNA levels for CS $(A)$ and COX2 $(B)$ in the liver of $Z$. viviparus. The relative amounts of CISY and COX2 were determined by RPA. Data were corrected for loading differences by using the $\beta$-actin signal (ACT-B). Values are means $\pm \mathrm{SE}$ and are expressed relative to the warmacclimated control group (day 0 ), which was set to 1 (arbitrary units; AU). Data were tested for outliers at the $95 \%$ significance level by using Nalimov's test (24). *Significant difference from the warmacclimated control group.

any significant change in HSI (Table 3). Baltic Sea eelpout showed a slightly but not significantly higher HSI than the North Sea population. Only the Antarctic eelpout had a significantly higher HSI compared with all other groups. The condition factors varied between 3.5 and 3.9 and were not affected by cold acclimation. No differences were visible between the two species.

\section{DISCUSSION}

Effects of cold on mitochondrial functioning. Inadequate oxygen supply likely is the first indicator of cold intolerance in both water and air breathers (cf. Refs. 26 and 27); however, compensatory mechanisms may already set in before such limits are reached. In ectothermic animals, long-term temperature shifts lead to compensatory changes in the levels of glycolytic and mitochondrial enzymes $(10,40)$. In our study, moderate cooling within the thermal tolerance window (40) excluded any onset of severe oxygen deficiency. Therefore, the observed changes in enzyme activity should represent an acclimation process initiated within the thermal tolerance window, as expected during progressive acclimatization to seasonal cold.

During cold acclimation, $Z$. viviparus from the North Sea showed a significant increase of CS activity in liver. The new steady state was reached about 10 days after the onset of cold exposure. A small increase in CS activity was also visible after long-term cold acclimation of Baltic Sea eelpout. In contrast, the activity of membrane-bound COX in both North Sea and Baltic Sea eelpout remained more or less unchanged during the acclimation process, with a transient trend toward rising in the beginning. This confirms previous findings (13) in which COX activity in liver of $Z$. viviparus remained unchanged even between animals acclimated to 18 vs. $0^{\circ} \mathrm{C}$.

Similar to the present data in eelpout, previous findings in cod showed that liver CS activity more clearly indicated mitochondrial responses to cold exposure than COX activity. Moreover, acclimatory changes in liver differed from those in muscle, because liver size increased in response to cold exposure, reflecting en-
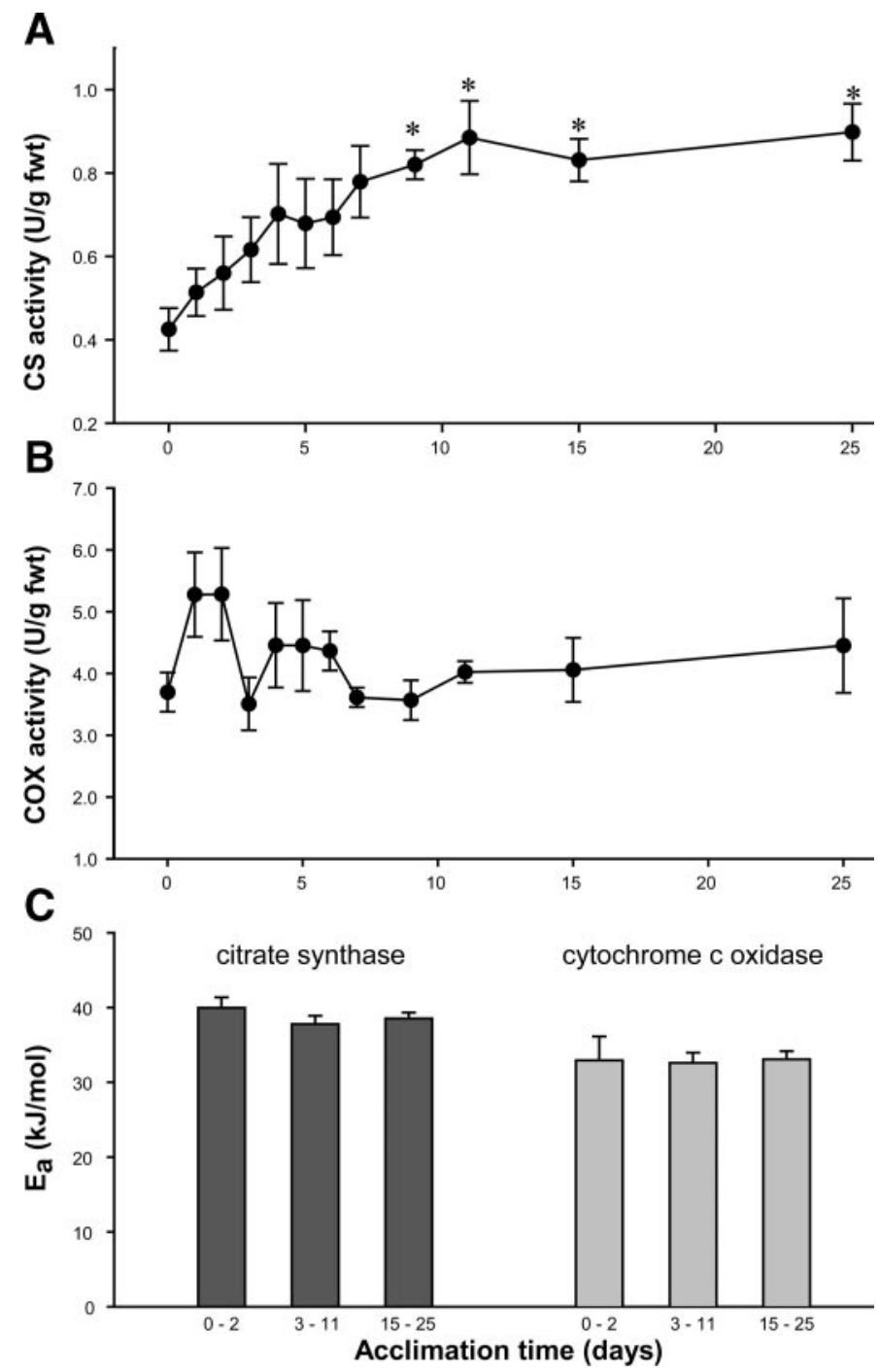

Fig. 4. Effects of temperature acclimation on activities of CS $(A)$ and $\mathrm{COX}(B)$ in the liver of $Z$. viviparus. Values are means $\pm \mathrm{SE}(n=$ $4-5$ ). The COX data were tested for outliers at the $95 \%$ significance level by using Nalimov's test (24). * Significant difference from the warm-acclimated control group. $C$ : for determination of activation energy $\left(\mathrm{E}_{\mathrm{a}}\right)$, data were pooled in 3 groups: days $0-2$ (before), day 3-11 (during), and days 15-25 (after acclimation). 
Table 2. Levels of CS mRNA or COX2 mRNA and activity in liver of long-term cold acclimated

Zoarces viviparus and cold adapted

Pachycara brachycephalum

\begin{tabular}{lrcc}
\hline \hline \multicolumn{1}{c}{ Species } & $\begin{array}{c}\text { Acclimation } \\
\text { Temperature }{ }^{\circ} \mathrm{C}\end{array}$ & $\begin{array}{c}\text { mRNA, relative } \\
\text { amount }\end{array}$ & $\begin{array}{c}\text { Activity, } \\
\mathrm{U} / g \text { fwt }\end{array}$ \\
\hline CS & & & \\
Z. viviparus, & & & \\
$\quad$ Baltic Sea & 3.5 & $1.74 \pm 0.13^{*}$ & $1.05 \pm 0.21$ \\
P. brachycephalum & 13.5 & $1.00 \pm 0.08$ & $0.80 \pm 0.13$ \\
$Z$. viviparus, & 0.0 & $1.65 \pm 0.06^{*}$ & $1.26 \pm 0.05^{\mathrm{a}}$ \\
$\quad$ North Sea & 3.5 & $1.65 \pm 0.03^{*}$ & $1.23 \pm 0.10^{\mathrm{a}}$ \\
$\quad$ & 10.0 & $1.52 \pm 0.14^{*}$ & $0.66 \pm 0.07$ \\
COX2 & & & \\
$Z$. viviparus, & 3.5 & $1.04 \pm 0.05$ & $3.09 \pm 0.33$ \\
$\quad$ Baltic Sea & 13.5 & $1.00 \pm 0.07$ & $3.49 \pm 0.20$ \\
$\quad$. brachycephalum & 0.0 & $1.05 \pm 0.16$ & $3.55 \pm 0.35$ \\
$Z$. viviparus, & & & \\
$\quad$ North Sea & 3.5 & $1.87 \pm 0.19^{*}$ & $6.25 \pm 0.85^{\mathrm{b}}$ \\
& 10.0 & $1.83 \pm 0.09^{*}$ & $5.35 \pm 0.27^{\mathrm{b}}$ \\
\hline
\end{tabular}

Values are given as means $\pm \mathrm{SE}(n=4-6)$. mRNA levels were determined by ribonuclease protection assay relative to the $\beta$-actin signal. The expression is normalized relative to the Baltic Sea eelpout acclimated to $13.5^{\circ} \mathrm{C}$. ${ }^{*}$ Significant difference from the warmacclimated Baltic Sea fish. Enzyme activities are depicted as ana-

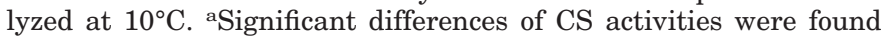
between cold-acclimated North Sea and Antarctic eelpout relative to the North Sea eelpout acclimated to $10^{\circ} \mathrm{C}$. bSignificant differences were found between Baltic Sea and Antarctic eelpout relative to the North Sea eelpout. fwt, Fresh weight.

hanced capacity per total tissue and thereby explaining fewer expressed capacity changes per gram of liver (17). In eelpout, hepatosomatic indices were not affected during or after cold acclimation (Table 3); therefore, the observed effects on enzymatic activities reflect the changes in all of the liver. In contrast to liver, COX activity in muscle of cold-exposed eelpout or cod increased in the cold $(13,17)$ but was again less sensitive to cold than CS activity as seen in cod. Battersby and Moyes (1) found that both CS and COX activities increased in parallel during cold acclimation in white and red muscle of trout, indicating a fixed ratio of matrix to cristae enzymes for both muscle types. The authors concluded that the observed increase might therefore be due mostly to changes in mitochondrial volume density. In red and white muscle of striped bass, an increase in mitochondrial volume density without changes in mitochondrial size and cristae surface density has in fact been observed during cold acclimation (5).

In contrast to the matrix enzyme CS, COX activity is affected by the lipid composition of the inner mitochondrial membrane. Wodtke $(42,43)$ demonstrated for carp red muscle that the specific activity of the enzyme was increased in cold-acclimated membranes when the lipid and fatty acid composition was changed. Trigari et al. (38), however, found no evidence for homeoviscous adaptation of mitochondrial membrane lipids in liver and heart of cold-acclimated sea bass (Dicentrarchus labrax). Accordingly, COX activity per milligram of mitochondrial protein was even decreased at lower acclimation temperatures. A similar pattern arises from the present study: in the liver of $Z$. viviparus, the increased activity of CS together with a more-or-lessconstant level of COX activity could in fact be due to an increased mitochondrial volume density at enhanced levels of membrane viscosity. A higher copy number of COX might be compensated for by incomplete or lacking homeoviscous adaptation, which causes a lower level of molecular activity.

The discrepancy between CS and COX activities would also indicate a relative increase in matrix over membrane functions in liver mitochondria. Mitochondria are not only involved in energy metabolism but also in anabolic processes with CS, providing excess citrate for example for lipid synthesis, which is frequently found enhanced in seasonal and latitudinal cold (cf. Ref. 27). These considerations might imply cold-induced functional changes of liver mitochondria. Clearly, mitochondrial functioning in cold- vs. warmacclimated tissues warrants further investigation.

Table 2 compares the acclimation process of CS activity and message in $Z$. viviparus from the North Sea and the Baltic Sea with the respective parameters in permanently cold-adapted confamilial Antarctic eelpout $P$. brachycephalum. At significantly higher levels of liver fresh weight (Table 3), the latter displayed liver CS activities similar to cold-acclimated North Sea and Baltic Sea eelpout, paralleled by high transcript levels. At first sight this contrasts with previous findings of significantly lower COX activity in liver in parallel with lower levels of mitochondrially encoded transcript (Ref. 13 and this study). However, this discrepancy becomes explainable in the light of the discussion of enhanced matrix- over membrane-bound functions in the cold. As seen in Fig. 5, the ratio of CS over COX activities rose by a factor of 2 in both temperate populations, whereas Antarctic eelpout demonstrated the highest CS-to-COX ratio. Therefore, cold adaptation and cold acclimation display similar patterns in that cold temperatures cause similar relative changes in the capacities of metabolic functions. Low COX and high

Table 3. Hepatosomatic indices and condition factors of long-term cold acclimated $Z$. viviparus and cold adapted $P$. brachycephalum

\begin{tabular}{lrcc}
\hline \hline \multicolumn{1}{c}{ Species } & $\begin{array}{c}\text { Acclimation } \\
\text { Temperature }{ }^{\circ} \mathrm{C}\end{array}$ & HSI \% & $\begin{array}{c}\text { Condition Factor, } \\
\mathrm{g} / \mathrm{cm}^{3} \cdot 1,000\end{array}$ \\
\hline$Z$. viviparus, & & & \\
$\quad$ Baltic Sea & 3.5 & $1.56 \pm 0.27$ & $3.69 \pm 0.28$ \\
& 13.5 & $1.90 \pm 0.36$ & $3.49 \pm 0.16$ \\
P. brachycephalum & 0.0 & $2.97 \pm 0.52^{*}$ & $3.82 \pm 0.11$ \\
$Z$. viviparus, & & & \\
$\quad$ North Sea & 3.5 & $1.39 \pm 0.18$ & $3.91 \pm 0.25$ \\
& 10.0 & $1.49 \pm 0.23$ & $3.84 \pm 0.21$ \\
\hline
\end{tabular}

Values are given as means $\pm \mathrm{SE}(\mathrm{n}=4-6)$. Hepatosomatic indices (HSI) were determined as [liver to body mass ratio] $\times 100 \%$. The condition factors were calculated according to Guderley et al (11): Condition factor $=\left[\right.$ mass $(\mathrm{g}) \times$ total length $\left.(\mathrm{cm})^{-3}\right] \times 1,000 . *$ Significant difference of Antarctic eelpout from Baltic Sea and North Sea eelpout. 


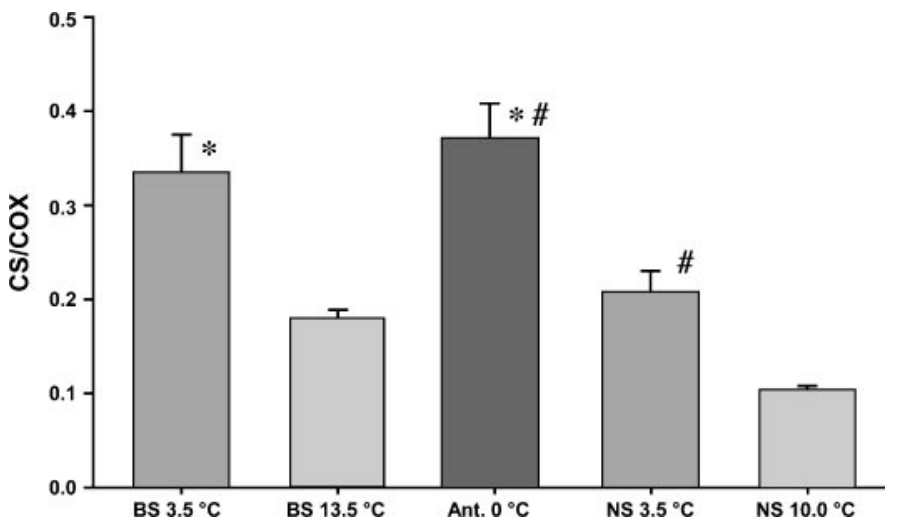

Fig. 5. Effect of acclimation and adaptation to cold on the ratio of CS to $\mathrm{COX}$ activities. Activity ratios were determined for each fish at $10^{\circ} \mathrm{C}$. Values are means $\pm \mathrm{SE}(n=4-6)$. $*$ Significant difference from the warm-acclimated Baltic Sea fish. \#Significant difference from the warm-acclimated North Sea eelpout.

CS activities in liver of Antarctic fish would in fact be in line with enhanced anabolic capacities in the cold, thereby supporting the high level of lipid accumulation observed in Antarctic fish (including eelpout; cf. Ref. 27). Moreover, high mitochondrial densities have been described for cold stenothermal species; however, these mitochondria exhibit lower ATP synthesis capacities than mitochondria from cold-adapted eurythermal species $(28,29)$.

Consistent with the present observation of enhanced CS capacities in $P$. brachycephalum, a compensatory increase of oxygen consumption was seen relative to warm-acclimated $Z$. viviparus acutely exposed to cold (40). These findings support the conclusion that Antarctic eelpout displays some level of metabolic cold compensation $(40,44)$.

Implications for mitochondrial proliferation. The investigation of time-dependent RNA expression in relation to the development of enzyme activities over time should provide some insight into the sites and levels of the regulation of mitochondrial proliferation. Since the activation energy of CS did not change with cold acclimation, posttranslational modifications can be neglected in this case. Then the resulting capacity of CS is the summed result of new protein synthesis and degradation. An increase in activity by a factor of 2 within 9 days can be achieved through increased synthesis rates, increased half-life of the protein, or both. In equilibrium (i.e., before and after the acclimation process), the same ratios of mRNA over protein quantities should result if protein levels are exclusively transcriptionally controlled. In this case, mRNA and protein levels would not necessarily change in parallel during the acclimation process, but a rise in mRNA content should at least precede the increment in protein levels. This is, however, not the case. In Z. viviparus, mRNA levels of CS were increased twofold only after 4-6 days of cold exposure, whereas enzyme capacity showed an immediate and continuous increment. Because enzyme activity likely reflects enzyme concentration (see RESULTS), this finding indicates that increased mRNA levels are not a precondition for enhanced accumulation of enzyme molecules and that posttranscriptional mechanisms play an important role. During long-term acclimation to the new temperature (Table 2), mRNA even returned to control levels, whereas elevated enzyme quantities were maintained. This change in mRNA-to-protein ratio together with the delayed onset of transcript accumulation once again emphasizes that enhanced transcript levels are not a prerequisite for compensatory translation to take place.

COX2 mRNA does not necessary reflect expression of all COX subunits nor represent the limiting subunit. Many studies (e.g., Refs. 1 and 13) have shown, however, that the mitochondrial subunits are transcribed in parallel, such that a similar increase for all mitochondria-encoded subunits can be expected. Nucleusencoded subunits could be regulated in a different way, but it has already been shown in $Z$. viviparus that the nucleus-encoded COX4 mRNA increased more strongly during cold acclimation than COX2 (13). Therefore, it seems reasonable to assume that any change in COX2 mRNA expression mirrors parallel changes (although possibly to different degrees) in the expression of both mitochondria- and nucleus-encoded subunits. COX2 mRNA displayed a similar (though equivocal) increment during initial cooling, with a similar delay and a similar pattern of return to control levels. Since both mRNAs have been determined relative to $\beta$-actin expression, it needs to be considered whether the pattern observed might be caused by a transient decrease in $\beta$-actin mRNA rather than by a net increase in CS or COX2 mRNA. However, since the absolute signal of $\beta$-actin mRNA showed no significant decrease during the relevant time period (data not shown), an increase of CS mRNA (and a less pronounced increase of COX mRNA) did, in fact, occur.

Overall, enzyme activities were not directly related to mRNA levels. Similar results have been obtained in other studies (37). During cold exposure, the nucleusencoded $\Delta^{9}$-desaturase of carp could be induced, paralleled by increasing mRNA levels; however, the activity of this enzyme remained high after return of the mRNA nearly to control levels (37). Comparing the time course of the different acclimation experiments, it becomes clear that the cold-induced increase in CS mRNA in the present study occurred quite late compared with the cold-induced desaturase response in carp (37). Regardless of the investigated enzyme system, however, acclimation to acute cold exposure was finalized in both cases within $\sim 10$ days.

Similar to our findings, an increase in CS activity preceded the increase in mRNA transcript during chronic stimulation of rabbit muscle (31), which also elicits mitochondrial proliferation $(14,19)$. For COX, an overcompensation of transcript level in cold-acclimated $Z$. viviparus muscle and liver was visible in our previous study (13) but not in the present study. Also, COX activity was increased in trout muscle at unchanged mRNA levels (1). All of these findings indicate that mRNA levels and enzymatic activities are only 
loosely correlated; however, increased mRNA levels may nonetheless accelerate the acclimation process and facilitate enzyme accumulation. These observations indicate an important role for either translational or, possibly, posttranslational regulation in the proliferation of mitochondria. This includes higher translational efficiency of specific mRNA and changes in the rate of protein degradation, which both influence enzyme levels. Clearly, it remains to be established which mechanisms would exert their specific effect on CS activity.

The suggested loose relationship between mRNA and enzyme protein levels is also emphasized by Fig. $6 \mathrm{~A}$. When normalized CS activity is plotted against normalized mRNA levels, only the warm-acclimated $Z$. viviparus from Baltic Sea, the cold-acclimated North Sea eelpout, and the cold-adapted $P$. brachycephalum match the line of identity, indicating that a doubling of message reflects a doubling of enzyme activity. In the case of COX, all data could be fitted on a linear regression line close to the line of identity (Fig. 6B). Therefore, activity and transcript levels are more closely correlated for COX than for CS, in line with a correlated accumulation of both mitochondrial mRNA and COX at rising mitochondrial densities. The fluctuating relationship between mRNA levels and CS activities may reflect its nuclear origin and/or the ambivalent function of this enzyme (see Effects of cold on mitochondrial functioning), which may require more differentiated regulation at several levels. $P$. brachycephalum demonstrated a correlated activity-to-mRNA ratio for both enzymes similar to the ratio seen in the warmacclimated control group of $Z$. viviparus, indicating a balanced situation in the cold-adapted species. Such ratios may be kept as low as possible, and this trend is visible in the thermal optimum of a species.

Cold acclimation obviously had different effects on both eurythermal populations. Starting from different control ratios, the cold-acclimated North Sea population showed an increased CS activity-to-mRNA ratio, whereas the Baltic Sea population displayed increased mRNA levels relative to enzyme activity. In our previous study, COX activities in the North Sea population (collected in winter) had also demonstrated increased mRNA levels relative to enzyme activity at $0^{\circ} \mathrm{C}$ acclimation temperature (13). The reasons for the variable patterns remain to be established. It needs to be considered that thermal compensation might be masked by reproductive and feeding activities as well as seasonal effects, especially in liver (cf. Ref. 8). Whereas stable hepatosomatic indices and condition factors argue against different feeding activities (Table 3), seasonal changes might be involved in the differences seen between North Sea specimens collected in winter (13) or late summer (this study).

Summary and conclusions. At the functional level, in both the eurythermal $Z$. viviparus and the closely related cold stenothermal $P$. brachycephalum, CS displayed metabolic cold compensation, whereas COX activity remained more or less constant, a finding suggestive of functional rearrangements within liver mito-

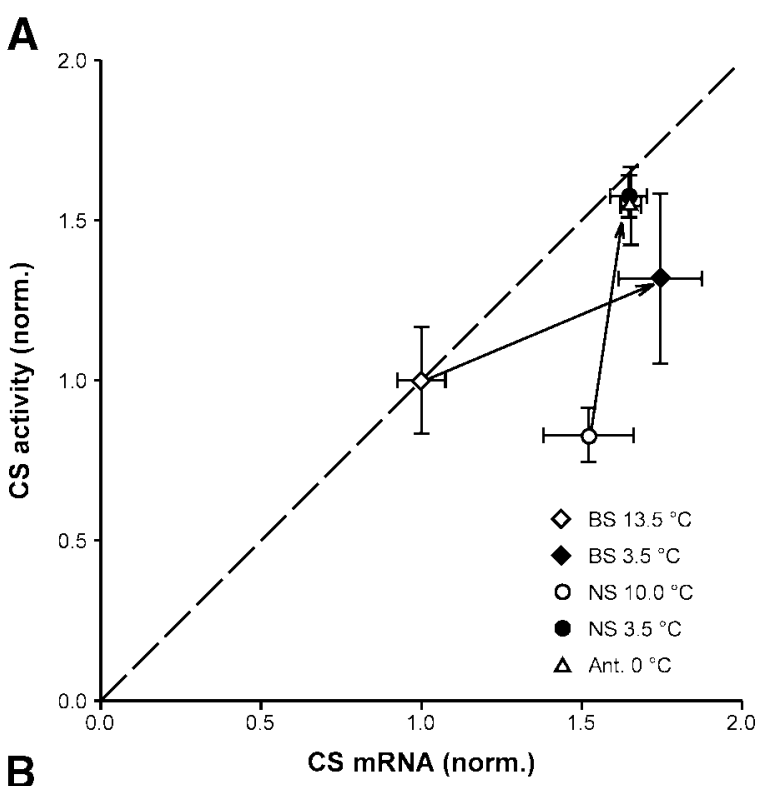

B

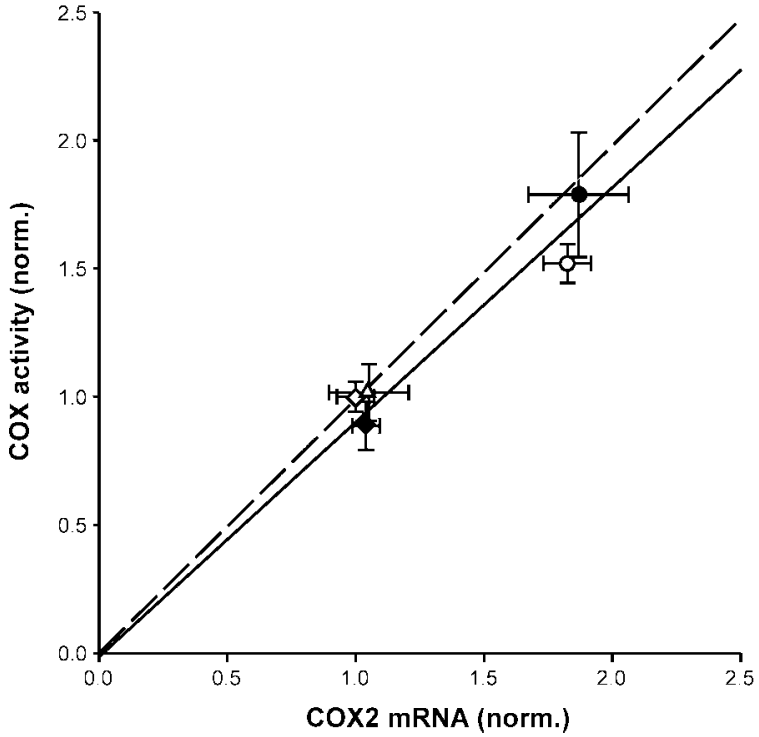

Fig. 6. Enzymatic activities versus mRNA levels in liver of long-term cold-acclimated $Z$. viviparus and cold-adapted Antarctic (Ant.) $P$. brachycephalum. A: CS. B: COX. Enzyme activities $\left(10^{\circ} \mathrm{C}\right.$ measuring temperature) and mRNA levels were normalized to the activity of warm-acclimated $Z$. viviparus from the Baltic Sea population. $\diamond, Z$. viviparus [Baltic Sea (BS); $13.5^{\circ} \mathrm{C}$ ]; $\bullet$. viviparus (Baltic Sea; $\left.3.5^{\circ} \mathrm{C}\right) ; \triangle, P$. brachycephalum $\left(0^{\circ} \mathrm{C}\right) ; \bullet, Z$. viviparus [North Sea (NS); $\left.3.5^{\circ} \mathrm{C}\right]$; $\bigcirc, Z$. viviparus (North Sea; $10.0^{\circ} \mathrm{C}$ ); dashed line, line of identity; solid line, linear regression for $\operatorname{COX}\left(y=0.91 x ; r^{2}=0.930\right)$. Values are means $\pm \mathrm{SE}(n=4-6)$.

chondria, which might support lipid biosynthesis. Since changes in COX numbers could be masked by changes in membrane composition and other effects, CS activity and the activity ratio of both enzymes might be a suitable marker for metabolic cold compensation at the mitochondrial level.

At the molecular level, we propose the following scenario of cold acclimation in summer eelpout for CS, with some applicability to COX. In an early phase, enzyme activities are adapted by means of enhanced net translation, possibly due to increased translation 
efficiency of existing mRNA or due to reduced protein degradation over time. For an establishment of final activity levels, increases in transcript levels in a second phase will help to overcome time constraints. Elevated enzyme activities were maintained after mRNA had more or less returned to control levels, indicating that residual mRNA levels were sufficient to maintain elevated steady-state enzyme levels, again likely due to reduced protein degradation.

The data suggest that acclimation of ectothermic organisms to thermal challenges proceeds more at the level of translation or protein stability than through complete control at the transcriptional level. As shown in earlier studies (40), energetic imbalances are not a precondition for such changes. Therefore, it must be established which signals trigger these processes.

We thank Elke Allers, Lars Hauptmann, Daniel Roecken, Christoph Schmitt, and Stefan Wolf from the University Bremen for engaged assistance.

\section{DISCLOSURES}

This work is a contribution to the ELOISE project: effects of climate induced temperature change on marine coastal fish (CLICOFI), funded by the European Union program "Climate and Environment," contract no. ENV4-CT97-0596.

\section{REFERENCES}

1. Battersby BJ and Moyes CD. Influence of acclimation temperature on mitochondrial DNA, RNA, and enzymes in skeletal muscle. Am J Physiol Regul Integr Comp Physiol 275: R905R912, 1998.

2. Clarke A. What is cold adaptation and how should we measure it? Am Zool 31: 81-92, 1991.

3. Clarke A and Johnston NM. Scaling of metabolic rate with body mass and temperature in teleost fish. J Anim Ecol 68: 893-905, 1999.

4. Crockett EL and Sidell BD. Some pathways of energy metabolism are cold adapted in Antarctic fishes. Physiol Zool 63: 472-488, 1990.

5. Egginton S and Sidell BD. Thermal acclimation induces adaptive changes in subcellular structure of fish skeletal muscle. Am J Physiol Regul Integr Comp Physiol 256: R1-R9, 1989.

6. Evans CT, Owens DD, Sumegi B, Kispal G, and Srere PA. Isolation, nucleotide sequence, and expression of a cDNA encoding pig citrate synthase. Biochemistry 27: 4680-4686, 1988.

7. Evans MJ and Scarpulla RC. NRF-1: a trans-activator of nuclear-encoded respiratory genes in animal cells. Genes Dev 4: 1023-1034, 1990.

8. Guderley H. Functional significance of metabolic responses to thermal acclimation in fish muscle. Am J Physiol Regul Integr Comp Physiol 259: R245-R252, 1990.

9. Guderley H. Temperature and growth rates as modulators of the metabolic capacities of fish muscle. In: Cold Ocean Physiology, edited by Pörtner HO and Playle RC. Cambridge, UK: Cambridge University Press, 1998.

10. Guderley $\mathbf{H}$ and Blier P. Thermal acclimation in fish: conservative and labile properties of swimming muscle. Can J Zool 66: 1105-1115, 1988.

11. Guderley H, Leroy PH, and Gagne A. Thermal acclimation, growth, and burst swimming of threespine stickleback: enzymatic correlates and influence of photoperiod. Physiol Biochem Zool 74: 66-74, 2001.

12. Haraguchi Y, Chung AB, Neill S, and Wallace DC. OXBOX and REBOX, overlapping promoter elements of the mitochondrial $\mathrm{F}_{0} \mathrm{~F}_{1}$-ATP synthase $\beta$ subunit gene. $J$ Biol Chem 269: 9330-9334, 1994

13. Hardewig I, Van Dijk PLM, Moyes CD, and Pörtner HO. Temperature-dependent expression of cytochrome-c oxidase in
Antarctic and temperate fish. Am J Physiol Regul Integr Comp Physiol 277: R508-R516, 1999.

14. Hood DA. Invited Review: contractile activity-induced mitochondrial biogenesis in skeletal muscle. J Appl Physiol 90: 11371157, 2001.

15. Johansen $\mathbf{S}$ and Bakke I. The complete mitochondrial DNA sequence of Atlantic cod (Gadus morhua): relevance to taxonomic studies among codfishes. Mol Mar Biol Biotechnol 5: 203-214, 1996.

16. Kawall HG, Torres JJ, Sidell BD, and Somero GN. Metabolic cold adaptation in Antarctic fishes: evidence from enzymatic activities of brain. Mar Biol (Berl) 140: 279-286, 2002.

17. Lannig G, Eckerle LG, Serendero I, Sartoris FJ, Fischer T, Knust R, Johansen T, and Pörtner HO. Temperature adaptation in eurythermal cod (Gadus morhua): a comparison of mitochondrial enzyme capacities in boreal and Arctic populations. Mar Biol (Berl) 142: 589-599, 2003.

18. Leary SC, Battersby BJ, and Moyes CD. Inter-tissue differences in mitochondrial enzyme activity, RNA and DNA in rainbow trout (Oncorhynchus mykiss). J Exp Biol 201: 3377-3384, 1998.

19. Leary SC and Moyes CD. The effect of bioenergetic stress and redox balance on the expression of genes critical to mitochondrial function. In: Environmental Stressors and Gene Reponses, edited by Storey KB, and Storey JM. Amsterdam: Elsevier, 2000.

20. Li K, Hodge JA, and Wallace DC. OXBOX, a positive transcriptional element of the heart-skeletal muscle ADP/ATP translocator gene. J Biol Chem 265: 20585-20588, 1990.

22. Moyes CD, Battersby BJ, and Leary SC. Regulation of muscle mitochondrial design. J Exp Biol 201: 299-307, 1998.

23. Moyes CD, Mathieu-Costello OA, Tsuchiya N, Filburn C, and Hansford RG. Mitochondrial biogenesis during cellular differentiation. Am J Physiol Cell Physiol 272: C1345-C1351, 1997.

24. Noack S. Statistische Auswertung von Meß- und Versuchsdaten mit Taschenrechner und Tischcomputer. Berlin: Walter de Gruyter, 1980.

25. Pörtner HO. Climate change and temperature-dependent biogeography: oxygen limitation of thermal tolerance in animals. Naturwissenschaften 88: 137-146, 2001.

26. Pörtner HO. Climate variations and the physiological basis of temperature dependent biogeography: systemic to molecular hierarchy of thermal tolerance in animals. Comp Biochem Physiol A Mol Integr Physiol 132: 739-761, 2002.

27. Pörtner HO. Physiological basis of temperature-dependent biogeography: trade-offs in muscle design and performance in polar ectotherms. J Exp Biol 205: 2217-2230, 2002.

28. Pörtner HO, Hardewig I, Sartoris FJ, and Van Dijk PLM. Energetic aspects of cold adaptation: critical temperatures in metabolic, ionic and acid-base regulation? In: Cold Ocean Physiology, edited by Pörtner HO and Playle RC. Cambridge, UK: Cambridge University Press, 1998.

29. Pörtner HO, Van Dijk PLM, Hardewig I, and Sommer A. Levels of metabolic cold adaptation: tradeoffs in eurythermal and stenothermal ectotherms. In: Antarctic Ecosystems: Models for a Wider Understanding, edited by Davison W and Williams CW. Christchurch, New Zealand: Caxton, 2000.

30. Sambrook J, Fritsch EF, and Maniatis T. Molecular Cloning. A Laboratory Manual. Cold Spring Harbor, NY: Cold Spring Habor, 1989.

31. Seedorf U, Leberer E, Kirschbaum BJ, and Pette D. Neural control of gene expression in skeletal muscle. Effects of chronic stimulation on lactate dehydrogenase isoenzymes and citrate synthase. Biochem J 239: 115-120, 1986.

32. Sidell BD, Driedzic WR, Stowe DB, and Johnston IA. Biochemical correlations of power development and metabolic fuel preferenda in fish hearts. Physiol Zool 60: 221-232, 1987.

33. Somero G. Temperature relationships; from molecules to biogeography. In: Handbook of Physiology. Comparative Physiology. Bethesda, MD: Am. Physiol. Soc., 1997, sect. 13, vol. II, chapt. 19, p. 1391-1444.

34. Sommer AM and Pörtner HO. Metabolic cold adaptation in the lugworm Arenicola marina: comparison of a North Sea and a White Sea population. Mar Ecol Prog Ser 240: 171-182, 2002. 
35. Steffensen JF. Metabolic cold adaptation of polar fish based on measurements of aerobic oxygen consumption: fact or artefact? Artefact! Comp Biochem Physiol A 132: 789-795, 2002.

36. St-Pierre J, Charest PM, and Guderley H. Relative contribution of quantitative and qualitative changes in mitochondria to metabolic compensation during seasonal acclimatisation of rainbow trout Oncorhynchus mykiss. J Exp Biol 201: 2961-2970, 1998.

37. Tiku PE, Gracey AY, Macartney AI, Beynon RJ, and Cossins AR. Cold-induced expression of $\Delta^{9}$-desaturase in carp by transcriptional and posttranslational mechanisms. Science 271: 815-818, 1996.

38. Trigari G, Pirini M, Ventrella V, Pagliarani A, Trombetti F, and Borgatti AR. Lipid composition and mitochondrial respiration in warm- and cold-adapted sea bass. Lipids 27: 371377, 1992.

39. Tschischka K, Abele D, and Pörtner HO. Mitochondrial oxyconformity and cold adaptation in the polychaete Nereis pelagica and the bivalve Arctica islandica from the Baltic and White Seas. J Exp Biol 203: 3355-3368, 2000.
40. Van Dijk PLM, Tesch C, Hardewig I, and Pörtner HO. Physiological disturbances at critically high temperatures: a comparison between stenothermal Antarctic and eurythermal temperate eelpouts (Zoarcidae). J Exp Biol 202: 3611-3621, 1999.

41. Venanzetti F, Cecconi F, Giorgi M, Cesaroni D, Sbordoni V, and Mariottini P. Cloning and characterization of the European seabass, Dicentrarchus labrax, mitochondrial genome. Curr Genet 26: 139-145, 1994.

42. Wodtke E. Temperature adaptation of biological membranes. Compensation of the molar activity of cytochrome c oxidase in the mitochondrial energy-transducing membrane during thermal acclimation of the carp (Cyprinus carpio L). Biochim Biophys Acta 640: 710-720, 1981.

43. Wodtke E. Temperature adaptation of biological membranes. The effects of acclimation temperature on the unsaturation of the main neutral and charged phospholipids in mitochondrial membranes of the carp (Cyprinus carpio L). Biochim Biophys Acta 640: 698-709, 1981.

44. Wohlschlag DE. An Antarctic fish with unusually low metabolism. Ecology 44: 557-564, 1963.

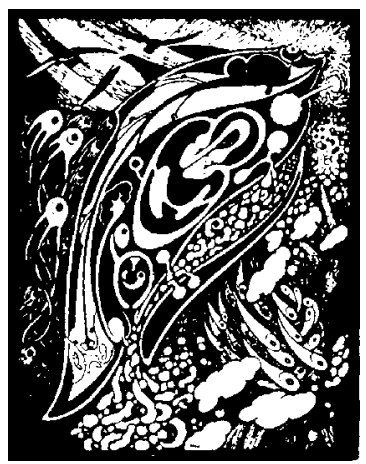

